${ }^{6}$ Bichet DG, Szatalowicz V, Chaimovitz C, Schrier RW. Role of vasopressin in abnormal water excretion in cirrhotic patients. Ann Intern Med 1982; 94:413-7.

${ }^{7}$ Lieberman FL, Denison EK, Reynold TB. The relationship of plasma volume, portal hypertension, ascites and renal sodium retention in cirrhosis: the overflow theory. Ann NY Acad Sci 1970;170:202-12.

${ }^{8}$ Wilkinson SP, Smith IK, Clarke M, et al. Intrarenal distribution of plasma flow in cirrhosis as measured by transit renography: relationship with plasma renin activity and sodium and water excretion. Clinical Science and Molecular Medicine 1977;52:469-75.

9 Perez-Ayuso RM, Arroyo V, Planas R, et al. Randomised comparative study of furosemide versus spironolactone in nonazotemic cirrhosis with ascites. Gastroenterology 1983;84:961-8.

${ }^{10}$ Leveen $\mathrm{HH}$, Christoudias G, Moon IP, Lift R, Falk G, Grosberg S. Peritoneovenous shunting for ascites. Ann Surg 1974;180:580-91.

11 Greig RD, Blendis LM, Langer B, Taylor BR, Colapinto LM. Renal and hemodynamic effects of the peritoneovenous shunt. Gastroenterology $1981 ; 80: 119-25$

12 Salem HF, Dudley FJ, Merrett A, Perkin J, Firkin BJ. Coagulopathy of peritoneovenous shunts. Gut 1983;24:412-7.

${ }^{13}$ Powell WJ, Klatskin G. Duration of survival in patients with Laennec's cirrhosis. Am $\mathcal{F}$ Med 1968;44:406-20.

\section{Atrial natriuretic factor: a new hormone?}

Only five years ago one of the most exciting recent major advances in physiology and medicine was made when natriuretic granules were discovered in the atria of the heart. Since then research has moved rapidly: the structure of this polypeptide and its precursors has been elucidated and the active material has been synthesised. Although much more work is needed before the role of the newly discovered substance (called atrial natriuretic factor, or ANF) in health and disease is known, there seems little doubt that a new chapter in physiology (cardiac, renal, and probably endocrine) is about to be written.

The story starts in 1979, when de Bold made the astute observation that microscopy of the atria of the heart showed material resembling the granules seen in secretory tissue. ${ }^{1}$ Recognising that the number of these granules varied according to the animal's sodium and water balance, he and his colleagues showed subsequently that there was a considerable increase in urinary sodium excretion in rats given an intravenous injection of atrial extract. ${ }^{2}$ Since then numerous workers have confirmed these results, ${ }^{3.14}$ and the natriuretic activity has been shown to be present in the granules. ${ }^{4}$

The peptide nature and amino acid content of the new substance were suggested by de Bold and Flynn ${ }^{15}$ and Grammer $e t a l,{ }^{10}$ the complete amino acid sequence of smaller molecular weight ( 28 amino acids) active peptides was shown by Flynn et al ${ }^{16}$ and others, ${ }^{17}{ }^{18}$ and a 73 amino acid polypeptide was subsequently sequenced. ${ }^{19}$ The identity of a 26 amino acid active peptide has been established and synthesised. ${ }^{20}$ By cloning techniques and sequence analysis of the cDNA the rat and human atrial natriuretic factor precursors have been shown to be composed of 152 amino acids. ${ }^{21-23}$ Atrial extracts have been shown to possess an enzyme which converts the large molecular weight material into the active small molecular weight polypeptide. ${ }^{24}$ More recently this conversion has also been effected with trypsin and kallikrein.

The results of early micropuncture studies s suggested that most of the activity of the atrial extract was associated with inhibition of reabsorption in the distal tubule, especially the collecting ducts. ${ }^{3}$ The vasodilator action of ANF was shown originally in atrial extracts ${ }^{25}$ and confirmed in the purified material. ${ }^{10}$ ANF was found to oppose the constricting action of noradrenaline ${ }^{10}$ and angiotensin II and histamine. ${ }^{90}$
Workers have differed about its effect on glomerular filtration rate, some finding little change (especially with small doses $^{9}$ ) but others finding a consistent one ${ }^{20}$ and especially a differential effect between the afferent and the efferent arterioles, so increasing the filtration fraction. ${ }^{20} \mathrm{An}$ increase in potassium excretion has also been shown with the synthetic (26 amino acid) material. ${ }^{20}$

The most up to date information was presented at the International Congress of Nephrology held in Los Angeles in June and at a preceding satellite meeting on natriuretic hormone and hypertension. Several groups had found no inhibition of sodium transport in toad bladder and no direct action on perfused portions of tubules. Amiloride, which blocks sodium entry on the apical side of tubular cells, did not inhibit the action of the atrial extracts; both plasma renin and aldosterone concentrations were depressed. With adrenal cells in vitro the ANF decreased aldosterone secretion whether stimulated by angiotensin II, corticotrophin, or potassium.

Radioimmunoassay studies showed that the right atrium contains about two to four times as much activity as the left. ANF is present in the circulation and its concentration is increased during volume expansion. Preliminary data suggest that it releases kallikrein from the kidney, which may be its mechanism of action given that it does not inhibit renal $\mathrm{Na} / \mathrm{K}$ ATPase. ${ }^{26}{ }^{27}$ Indomethacin does not abolish the effect of ANF and so presumably prostaglandins are not concerned in its action. In clip hypertension in rats ANF lowers blood pressure to normal even when it does not produce natriuresis.

The reported rise in ANF with volume expansion would suggest that ANF might explain the observation of nearly 30 years ago that stretching the atria increases the urinary volume. ${ }^{28}$ Since then extensive studies have shown that atrial receptor activity is increased during stretch of the atrium and that the renal response depends on an intact vagus. ${ }^{29} 30$ Whether the release of ANF depends on an intact vagus has yet to be determined, but if it does the link may explain the long forgotten observation of Mills et al in 1958 that a rapid fall in aldosterone concentrations from previously high levels depends on the vagus being intact. ${ }^{31}$ The effect of ANF on the cardiovasculature and kidney are not prevented by atropine. The depression of aldosterone plasma concentrations and secretion in vitro by ANF fills a gap in our knowledge which the action of dopamine did not explain. ${ }^{32-35}$

The vascular effects of ANF on the kidney would be expected to release kallikrein, as do all vasodilators. ${ }^{36-38}$ If this were so this action would also explain the antagonism of antidiuretic hormone which activation of the renal kallikrein/ kinin system is known to produce. ${ }^{36} 39$

Innumerable questions now spring to mind. What happens to the release of ANF when the atria are in fibrillation? What happens in heart failure; does ANF fail to be released or does the kidney become resistant to it in some way? Evidence suggests that negative pressure breathing, which increases salt and water excretion, ${ }^{40}$ releases a substance acting like ANF. Is ANF the substance which the work of de Wardener and Mills $\mathrm{s}^{41}{ }^{42}$ first postulated over 20 years ago when they said that a circulating substance with a short half life, other than aldosterone, played a major part in the excretion of sodium? Is the action on the renal vasculature the explanation for the failure of a kidney wrapped in latex to be able to increase sodium and kallikrein excretion in response to expansion of the blood volume? ${ }^{36}$ (This series of experiments led to the statement that if a circulating natriuretic hormone existed then it had to act on the renal vasculature and not on the renal tubules. ${ }^{43}$ ) 
How do all the data on the presence of a circulating inhibitor of the sodium pump in essential hypertension fit in with the action of ANF, ${ }^{4455}$ or are the two concepts independent? Is the low kallikrein excretion in patients with essential hypertension ${ }^{56}$ and their normotensive children ${ }^{57}$ a limiting factor in natriuresis, entailing an alternative natriuretic mechanism which is related to the hypertension? Undoubtedly there will be an enormous surge in physiological and clinical research and much work will have to be carried out before these interesting results are established on a scientific basis and the clinical questions can be answered.

IVOR H MILLS

Professor of Medicine,

University of Cambridge Clinical School,

Cambridge CB2 2QQ
45 Overbeck HW. Vascular reponses to cations, osmolality and angiotensin in renal hypertensive dogs. Am f Physiol 1972;223:1358-64.

RD, Patrick J, Jones NF. Abnormal leucocyte composition and sodium transport in essential hypertension. Lancet 1975; ;i: $1003-5$.

from patients with essential hypertension and the effect of treatment 1975;48(suppl): : $169-70$

48 Overbeck HW, Pamnani MB, Akera T, Brody TM, Haddy FJ. Depressed function of a ouabainsensitive sodium-potassium pump in blood vessels from renal hypertensive dogs. Circ Res 1976;38(suppl II):48-52.

49 Blaustein MP. Sodium ions, calcium ions, blood pressure, regulation and hypertension: a reassessment and a hypothesis. Am $\mathcal{H}$ Physiol 1977;232:165-73.

Haddy FJ, Overbeck HW. The role of humoral agents in volume expanded hypertension. Life Sci

Pamnani MB, Clough DL, Huot SJ, Haddy FJ. Vascular sodium-potasi
models of experimental hypertension. Clin Sci 1980;59(suppl):179-81.

52 de Wardener HE, MacGregor GA. Dahl's hypothesis that a saluretic substance may be responsible for a sustained rise in arterial pressure: its possible role in essential hypertension. Kidney Int 1980;18:1-9.

3 Pamnani MB, Buggy J, Huot SJ, Haddy FJ. Studies on the role of a humoral sodium transport inhibitor and the anteroventral third ventricle $\left(\mathrm{AV}_{3} \mathrm{~V}\right)$ in experimental low renin hypertension. Clin Sci 1981;61(suppl): 57-60.

4 Poston L, Sewell RB, Wilkinson SP, et al. Evidence for a circulating sodium transport inhibitor in essential hypertension. $\mathrm{Br}$ Med $\mathcal{J}$ 1981;282:847-9.

5 Huot SJ, Pamnani MB, Clough DL, et al. Sodium-potassium pump activity in reduced renal-mass hypertension. Hypertension 1983;5(suppl I): $94-100$

56 Margolius HS, Geller RG, Pisano JJ, Sjoerdsma A. Altered urinary kallikrein excretion in human hypertension. Lancet 1971 ; ii: $1063-5$.

Zinner SH, Margolius HS, Rosner B, Keiser HR, Kass EH. Familial aggregation of urinary kallikrein concentration in childh
Am J Epidemiol 1976;104:124-32.

de Bold AJ. Heart atria granularity effects of changes in water electrolyte balance. Proc Soc Exp Biol Med 1979;161:508-11.

de Bold AJ, Borenstein HB, Veress AT, Sonnenberg $\mathrm{H}$. A rapid and potent natriuretic response to intravenous injection of atrial myocardial extract in rats. Life Sci 1981;28:89-94.

Briggs JP, Steipe B, Schubert G, Schnermann J. Micropuncture studies of the renal effects of atrial natriuretic substance. Pflugers Arch 1982;395:271-6.

Garcia R, Cantin M, Thibault G, Ong H, Genest J. Relationship of specific granules to the natriuretic and diuretic activity of rat atria. Experientia 1982;38: 1071-3

Sonnenberg $\mathrm{H}$, Cupples WA, de Bold AJ, Veress AT. Intrarenal localization of the natriuretic effect of cardiac atrial extract. Can $\mathcal{Y}$ Physiol P harmacol 1982;60:1149-52.

Trippodo NC, MacPhee AA, Cole FE, Blakesley HL. Partial chemical char
natriuretic substance in rat atrial tissue. Proc Soc Exp Biol Med 1982;170:502-8.

natriuretic substance in rat atrial tissue. Proc Soc Exp Biol Med 1982;170:502-8. de Bold AJ, Salerno TA. Natriuretic activity of extracts obtained from
and from various rat tissues. Can P Physiol Pharmacol 1983;61:127-30.

and from various rat tissues. Can $\mathcal{F}$ Physiol Pharmacol 1983;61: 127.30.
Borenstein HB, Cupples WA, Sonnenberg H, Veress AT. The effect of a natriuretic atrial extract on renal haemodynamics and urinary excretion in anaesthetized rats. I Physiol 1983;334:133-40. Baines AD, de Bold AJ, Sonnenberg $\mathrm{H}$. Natriuretic effect of atrial extract on isolated perfused rat

kidney. Can Y Physiol Pharmacol 1983;61:1462-6.
Grammer RT, Fukumi H, Inagami T, Misono KS. Rat atrial natriuretic factor. Purification and vasorelaxant activity. Biochem Biophys Res Commun 1983;116:696-703.

Keeler R, Azzarolo AM. Effects of atrial natriuretic factor on renal handling of water and electrolytes in rats. Can $f$ Physiol Pharmacol 1983;61:996-1002.

12 Nemeh MN, Gilmore JP. Natriuretic activity of human and monkey atria. Circ Res 1983;53:420-3. Pollock DM, Banks RO. Effect of atrial extract on renal function in the rat. Clin Sci
1983;65:47.55.

Sonnenberg H, Milojevic S, Chong CK, Veress AT. Atrial natriuretic
content in spontaneously hypertensive rats. Hypertension 1983;5:672-5.

15 de Bold AJ, Flynn TG. Cardionatrin I- A novel heart peptide with potent diuretic and natriuretic

properties. Life Sci 1983;33:297-302. A the amino acid sequence of an atrial peptide with poten
16 Flynn TG, de Bold ML, de Bold AJ. The

diuretic and natriuretic properties. Biochem Biophys Res Commun 1983;117:859-65.

17 Thibault G, Garcia R, Seidah NG, et al. Purification of 3 rat atrial natriuretic factors and their

amino acid composition. FEBS Lett 1983;164:286-90.

Kangawa K, Matsuo $H$. Purification and complete amino acid sequence of $\alpha$-human atrial natriuretic polypeptide ( $\alpha$-hANP). Bioch Biophys Res Commun 1984;118:131-9.

Thibault G, Garcia $R$, Cantin $M$, et al. Primary structure of a high $M_{\mathrm{r}}$ form of rat atrial natriuretic factor FEBS Lett 1984;167:352-6.

20 Atlas SA, Kleinert HD, Camargo $\mathrm{MJ}$, et al. Purification, sequencing and synthesis of natriuretic and vasoactive rat atrial peptide. Nature 1984;309:717-9.

Maki M, Takayanagi R, Misono KS, Pandey KN, Tibbetts C, Inagami T. Structure of rat atrial natriuretic factor precursor deduced from cDNA sequence. Nature 1984;309:722-4

Oikawa $S$, Imai $M$, Ueno A, et al. Cloning and sequence analysis of $\mathrm{CDNA}$ encoding a precursor for

human atrial natriuretic polypeptide. Nature 1984;309:724-6.

Yamanaka $M$, Greenberg B, Johnson $L$, et al. Cloning and sequence analysis of the cDNA for the

24 rat atrial natriuretic factor precursor. Nature 1984;309:719-22.

to low molecular weight forms. Biochem Biophys Res Commun 1984;119:282-8.

Currie MG, Geller DM, Cole BR, et al. Bioactive cardiac substances: potent vasorelaxant activity

in mammalian atria. Science 1983;221:71-3.
Pollock DM, Mullins MM, Banks RO. Failure of atrial myocardial extract to inhibit renal $\mathrm{Na}^{+}$, $\mathrm{K}^{+}-\mathrm{ATP}$ ase. Renal Physiol 1983;6:295-9.

27 Thibault G, Garcia R, Cantin M, Genest J. Atrial natriuretic factor. Characterization and partial

28 purification. Hypertension 1983;5(suppl I):75-80.

Henry JP, Gauer OH, Reeves JL. Evidence of the atrial location of receptors influencing urine

29 Linden RJ, Kappagoda CT. Atrial receptors. Cambridge: Cambridge University Press, 1982.

205 .
31 Mills, Casper A, Bartter FC. On the role of the vagus in the control of aldosterone secretion. Science 1958;128:1140-1.

32 Frisina N, Costa G, Buemi M. Evidence for dopaminergic control of aldosterone in man. Clin Endocrinol (Oxf 1983;19:741-5.

33 Lun S, Espiner EA, Nicholls MG, Hart DS. Lack of direct effect of dopamine on aldosterone secretion in vivo. Endocrinology 1983;112:60-3.

Wilson TA, Kaiser DL, Carey RM. Dopaminergic inhibition of aldosterone secretion in man is independent of the autonomic nervous.system. I Clin Endocrinol Metab 1983;57:200-3.

35 Aguilera G, Catt KJ. Dopaminergic modulation of aldosterone secretion in the rat. Endocrinology

1984;114: 176-81.
36 Mills IH, Macfarlane NAA, Ward PE, Obika LFO. The renal kallikrein-kinin system and the
refulation of all and water excretion. Fed Proc 1976;35:181-8. regulation of salt and water excretion. Fed Proc 1976;35:181-8

Mils $1 \mathrm{H}$, Obika LFO. Increased urinary kallikrein excretion during prostaglandin $\mathrm{E}_{1}$ infusion in anaesthetized dogs and its relation to natriuresis and diuresis. $\mathcal{F}$ Physiol 1977;273:459-74.

Mubstances and its relationship to the excretion of salt and water. Contrib Nephrol 1978;12-132-44.

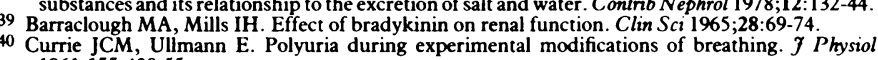
1961; 155:438-55.

${ }^{4}$ de Wardener HE, Mills IH, Clapham WF, Hayter CJ. Studies on the efferent mechanism of the sodium diuresis which follows the administration of intravenous saline in the dog. Clin $\mathrm{Scl}$ 1961;21:249-58.

42 Mills IH, de Wardener HE, Hayter CJ, Clapham WF. Studies on the afferent mechanism of the

43 Modium chloride diuresis which follows intravenous saline in the dog. Clin Sci 1961;21:259-64. Mills IH, Ward PE, Macfarlane NAA, Obika LFO. The role of renal kallikrein in diuresis and
natriuresis. In: Kramer HJ, Krück F, eds. Natriuretic hormone. Berlin: Springer-Verlag,

Bricker NS, Klahr S, Puckerson M, Schultze RG, Avioli V, Burge SJ. In vitro assay for a humoral
substance present during volume expansion and uraemia Nature 1968;219:1058-9.

substance present during volume expansion and uraemia. Nature 1968;219: 1058-9.

\section{Unmet need in chronic disability}

Have we one of the worst disability management services in Europe? The question was asked at the inaugural meeting of the Medical Disability Society, in a session entitled "The needs of those with multiple sclerosis are not met."

The fact that patients are still wrecked by deformity, said D L McLellan, is proof that needs are not met, for most contractures are unnecessary. He drew particular attention to a new method from Sweden for reducing spasticity by maintaining muscle stretch: if this is done for half an hour with the help of apparatus (and it could be done at home) the effect may last for several hours' ; the method may be better than the use of antispastic drugs. With further evaluation this might become a widespread technique, and perhaps remarkably it has hardly been tried so far in Britain. R C L Feneley, speaking about incontinence, referred to a series in which eight of the 16 patients with catheters had leaks and two others had appliances that leaked. ${ }^{2}$ He believed that intermittent self catheterisation was a great advance that should be considered more often; and his conclusion was that since no doctor could know about all the possible continence devices there was a need for a continence adviser, possibly a nurse with comprehensive knowledge. In the prevention of pressure sores the needs of patients will not be met, suggested D Bader, until a physiological pressure monitor becomes available. A continuous tape recording device for attachment to wheelchairs is being developed at the Oxford Orthopaedic Engineering Centre, but meanwhile pressure on the buttocks may be reduced by using high density foam cushions of large surface area, with the surface scored. Considering the problems of mobility, J A A Hunter referred to his study of wheelchair users in south east Scotland, in which about half the patients with multiple sclerosis reported technical or design problems with their wheelchairs. Patients and also the medical profession, he concluded, need to have better information about what is available and be helped to make better use of it-an even more urgent task than improving what we have.

"If you have multiple sclerosis," someone said in the discussion, quoting a patient, "no one wants to know." 